\title{
The effect of movement intervention for women attending courses in weight reduction
}

\author{
Tereza Sofková*, Miroslava Přidalová, and Jana Pelclová \\ Faculty of Physical Culture, Palacký University, Olomouc, Czech Republic
}

Copyright: (C) 2014 T. Sofková et al. This is an open access article licensed under the Creative Commons Attribution License (http:// creativecommons.org/licenses/by/4.0/).

\begin{abstract}
Background: Accelerated pace of life and consumerism leads to an increase in obesity. The key element in programs to reduce overweight and obesity is regular physical activity (PA) by means of a healthy lifestyle. Walking, which can be simply assessed by pedometers is appropriate PA that is accessible to everyone, regardless of age and gender. Aim: The aim of our study was to analyse the effect of courses in weight reduction to the selected body composition (BC) parameters in the obese and overweight women of various age and PA level. Methods: 124 women with existing sendenary lifestyles participated in the study, they were differentiated by age $(<40$ years: aged $31.3 \pm 5.4$ years, body weight of $88.2 \pm 18.5 \mathrm{~kg}$, body height of $166.5 \pm 9.5 \mathrm{~cm}$ and $\geq 40$ years: aged $51.6 \pm 7.5$ years, body weight of $88.9 \pm 13.3 \mathrm{~kg}$, body height of $163.8 \pm 8.2 \mathrm{~cm}$ ). We divided the monitored sample into sub-groups according to the level of their PA. To determine the average daily number of footsteps during the PA the Yamax pedometer was used. InBody 720 device using the Direct Multi-frequency Bioelectrical Impedance Analysis Method (DSM-BIA Method) was used to measure and analyse the BC. Results: Based on monitoring of PA and BC health risk indicators the effect of the exercise program, which included cognitive behavioural therapy, showed a decline in body mass index (BMI) and body fat expressed in percentages (PBF) and in the decrease of the visceral fat area (VFA). The amount of fat-free mass (FFM) remained the same. Preceding the therapy the BMI average was within the obesity group (BMI $>30 \mathrm{~kg} / \mathrm{m}^{2}$ ). Following the three month therapy we observed in women with a higher level of PA a shift to the overweight group. Therapy contributed to a reduction in PBF from $2.4 \%$ to $3.9 \%$ even though the women's groups were still classified as obese (> 35\%). During the repeated measurements significant changes $(p<.05)$ occurred only in the VFA in relation to different ages. Conclusions: Research studies have shown positive relationships between the increase in PA and changes in health risk indicators. Observance of the recommended number of 10,000 footsteps per day primarily prevents the increase in body fat mass (BFM) and maintains FFM. Taking up a weight reduction program is essential when commencing the weight loss process in the course of lifestyle change.
\end{abstract}

Keywords: body composition health risk indicators, obesity, walking, healthy lifestyle, weight loss program

\section{Introduction}

Regular physical activity (PA) ensures the avoidance of obesity and it is a natural way to reduce it. Regular PA promotes health, prevents the onset of a number of diseases as well as improvement in social networking and quality of life (Anderson \& Butcher, 2006; Miles, 2007).

Factors that influence lifestyle are the environment, PA, demographics, cultural differences, and genetic, ethical, ethnic, and political factors, etc. Our

\footnotetext{
* Address for correspondence: Tereza Sofková, Department of Anthropology and Health Education, Faculty of Education, Palacký University, Žižkovo nám. 5, 77140 Olomouc, Czech Republic. E-mail: tereza.sofkova@upol.cz
}

aim is to positively streamline the attitude and reaction of responsible government bodies to the increase in "unhealthy lifestyle" caused particularly by the excess daily energy intake, poor dietary habits and lack of PA which, in combination, often lead to obesity and other non-communicable diseases. Within Europe strategic papers were published (e.g. White paper on sport, White paper - strategy for Europe) relating to the health issues such as nutrition, overweight, obesity and lack of PA (European Communities Commission, 2007).

In the Czech Republic more than half of the adult population is overweight (Láchová \& Daňková, 2010). On the European scale the Czech Republic is in the 10th place, with $17 \%$ of the population obese, an increase of 3\% since 1999 (OECD, 2010). Ball, Crawford, and Owen (2000) reported that for women 
being overweight does create a barrier to PA in $6.2 \%$ and being obese in $22.6 \%$. Worldwide, every year the increasing number of people is at risk of being overweight and obese, thus it is essential to find ways to encourage people to carry out the simple recommendations for different types of PA (Saris et al., 2003). However, society in general is not yet ready to adopt such strategic recommendations.

Optimal body composition (BC) is considered as the suitable indicator of the body condition and its fitness. Suitable indicators provide evidence that the somatic state change relates to the individual body composition change, especially fat and fat-free mass and body composition health indicators, such as Body Fat Mass Index (BFMI), Fat-Free Mass Index (FFMI), Visceral Fat Area (VFA), Obesity Index (OI), and Body Cell Mass Index (BCMI). Thus, the long-term reduction in $\mathrm{PA}$ is reflected in the appearance of the undesirable body fractions and $\mathrm{BC}$ health risks indicators (Gába et al., 2009; Heyward \& Wagner, 2004; Kyle, Morabia, Schutz, \& Pichard, 2004; Přidalová, Riegerová, Dostálová, \& Gába, 2008; Přidalová, Sofková, Dostálová, \& Gába, 2011).

For all intents and purposes, the Habitual Physical Activity (HPA) includes all daily activities. One way to measure the HPA is by using pedometers. This form of monitoring allows the general public access to the basic information about activity level (Sigmund \& Frömel, 2005). The day "universal" standard recommends to walk at least 10,000 footsteps to promote health (Roubenoff, 2000; Saris et al., 2003; Sigmund, Frömel, \& Neuls, 2005; Tudor-Locke et al., 2001; Tudor-Locke \& Bassett, 2004; U. S. Department of Health and Human Services, 2008).

Cognitive behavioural therapy, used among others by the STOB (STop OBesity) courses in weight reduction, promotes new approach to nutrition and exercise programs (Málková, 2005). A key constituent in weight loss programs is PA as it relates to the reduced weight long-term maintenance. It prevents the decrease in basal metabolism and encourages fat-free mass (Andersen, 2003; Donnelly et al., 2003; Garrow \& Summerbell, 1995; Přidalová et al., 2011). Walking is an appropriate exercise to maintain cardiovascular fitness. To sustain fat-free body mass and power capability, anaerobic activity and isometric exercise is also required (Albright \& Thompson, 2006; Mazzeo et al., 1998; Ready et al., 1995).

Weight loss via combined intervention (diet and exercise) brings the decreased incidence of the mechanical and metabolic obesity complications (Straznicky et al., 2009). However, Ross, and Janiszewski (2008) in their study proved that whilst overall body weight reduction is associated to a significant decrease in cardiovascular risk related to obesity (a reason why it remains the desired outcome of relevant treatment strategies), increased PA even in cases of minimal or zero weight changes, can increase body fitness and thus positively influence health. King, Hopkins, Caudwell, Stubbs, and Blundell (2009) found that PA without weight reduction leads to reduced risks of obesity complications, as well as to a better mental state, which supports adherence to the reduction programme.

\begin{abstract}
Aim
The aim of our work was to analyse the effect of courses in weight reduction to the $\mathrm{BC}$ health indicators in the obese and overweight women with various age and PA.
\end{abstract}

\section{Methods}

The monitored sample included 124 women with existing sedentary lifestyles, aged between 20 and 60 years. The sample was divided into two groups according to age, the first group included women $<40$ years (aged $31.3 \pm 5.4$ years, body weight of $88.2 \pm 18.5 \mathrm{~kg}$, body height of $166.5 \pm 9.5 \mathrm{~cm}$ ) and the second group $\geq 40$ years (aged 51.6 \pm 7.5 years, body weight of $88.9 \pm 13.3 \mathrm{~kg}$, body height of $163.8 \pm 8.2 \mathrm{~cm}$ ). The 40 years age "dividing" limit was selected by the onset of menopause and was based on literature review (Cibula, Henzl, \& Živný, 2002; Fanta, 2007; McKinley, Brambilla, \& Posner, 1992).

The research part of the project was carried out during 2011 and 2012 in 6 courses of weight reduction, which were run by female instructors. Somatic status diagnosis at the beginning and end of the course, like monitoring of PA, was carried out by the Faculty of Physical Culture, Palacký University long-term program team and this activity is outside the course. PA monitoring is not included in the standard section of the course. Each woman signed agreement to carry out measurements within the course, was familiarised with the research particulars and instructed in the use of the accelerometer. The women were always acquainted with the results of input and output examinations and the subsequent result analysis relating to the whole group. The project was approved by the Ethical Committee of the Faculty of Physical Culture, Palacký University, Olomouc.

\section{Measurement methods}

Diagnosis of body composition (BC) was carried out by the InBody 720 (Biospace, Seoul, South Korea) device using the Direct multi-frequency bioelectrical 
impedance analysis method. The principle of the bioelectrical impedance method is based on the difference in the propagation of high-frequency alternating electric current of varying intensity in different biological matter. This method is non-invasive and time saving. The device differentiates body weight into three components: total body water (intracellular and extracellular water), dry matter (proteins and minerals) and body fat. The used method is unified; measurement was carried out under the standard conditions given by the device Operation manual (Biospace, 2008). In advance of each measurement the study group members were acquainted with the rules; compliance with the rules was essential to attain valid information relating to body composition.

Pedometers were used to monitor their PA throughout the course. Eleven week exercise activity was monitored using the Yamex Digi Walker SW-701 pedometer with the number of footsteps entered in the exercise log sheet. The pedometer is an electronic device measuring vertical oscillations with the aggregate daily number of footsteps showed on the display. In general, pedometers are most accurate in determining the number of footsteps and recommended to monitor PA (Schneider, Crouter, \& Bassett, 2004; Tudor-Locke \& Myers, 2001).

The daily number of footsteps, recorded by the pedometer, does not include any other physical activities (e.g. swimming, cycling etc.); however it gives a good general guide and motivation. Incentive in monitoring the number of footsteps is reflected in the pursuit to increase the number of footsteps per day and also encourages competition among women. The pedometer also serves as an important cognisance of HPA and is regarded as means to increase the level of PA (Bravata et al., 2007; Lubans, Morgan, \& Tudor-Locke, 2009) in all age groups and for different activities, with the greatest impact achieved by women (Kang, Marshall, Barreira, \& Lee, 2009).

\section{Intervention}

The theoretical subject matter of the 11 week course included modification of the existing lifestyle habits, nutrition programs and psychotherapy (cognitive behavioural therapy). This psychological method of treatment is based on the fact that inappropriate eating and exercise habits are learned and therefore, it is possible to change them. Psychotherapy and relaxation techniques in weight-loss programs are also necessary for obese individuals to overcome negative emotions, stress, depression and anxiety. The methodology was applied to a group as the group members supported each other. Reducing diet was the basis of nutritional intervention and was equivalent to the caloric value of
$5,000-6,500 \mathrm{~kJ}$ per day at a frequency of 5 meals per day (Málková, 2005).

Theory included 60 minutes per week of cognitive behavioural therapy with an analysis of diet and PA for the previous week. Owing to the recording of the PA level by the use of the Yamax pedometer, subjects were able to monitor the number of steps per day. The practical element of the course included: a) exercise (60 minute unit) consisted of the initial phase (40-45 minutes) - warm-up, stretching, aerobic fitness; and compensation phase (15 minutes) - stretching; b) relaxation; and c) anti-stress exercises.

\section{Measured variables}

Within the study we used standardised anthropometric methods for the determination of basic somatic parameters and somatic indices (Riegerová, Přidalová, \& Ulbrichová, 2006). The relative health risks were assessed by the BMI and WHR somatic indexes, fat and VFA and the Obesity Index (OI). We consider the BMI as the essential factor to classify underweight, overweight and obesity and the subsequent health risks associated with it (WHO, 2004). To evaluate the type of obesity the WHR was used (determined by the anthropometric method).

Bioelectrical impedance analysis, first and foremost, assessed the total body water (TBW) and subsequently fat-free mass (FFM, $\mathrm{kg}, \%$ ). For the obesity and overweight assessment we used the body fat mass (BFM, kg), body fat mass index (BFMI) and body fat percentage (BFP, \%); for the type of obesity assessment we used WHR and visceral fat area (VFA, $\mathrm{cm}^{2}$ ) measured by the InBody 720 device. To assess objectively the health relative risks the body fat mass index (BFMI) and fat-free mass index (FFMI) were used, among others. The sum of BFMI and FFMI gives the BMI value (Kyle, Morabia, Schutz, \& Pichard, 2004). Obesity Index (OI) is given as the proportion of the actual body weight relative to the ideal weight (\%). We also investigated the following: OTHM - mesosternal chest circumference, OTHX - chest circumference measured at xiphisternum, waist circumference as the narrowest part of the torso, abdominal circumference (Cf) over the navel and the maximum Cf over the gluteus maximus.

\section{Data processing}

Descriptive statistics and data analysis were carried out using the Statistica (Version 10.0; StatSoft, Tulsa, OK, USA) program. Using cluster analysis method by the K-average method, we further divided the sample into two groups, namely women with lower PA $(8,000$ footsteps per day) and women with higher PA (12,000 footsteps per day) (Table 1). In the course of the result 
evaluation we taken into account the degree and type of obesity using combination of waist and hip ratio (WHR: within the standard: $<0.85$, above average: 20.85 ) and body mass index (BMI: within the standard: $18.5-24.9 \mathrm{~kg} / \mathrm{m}^{2}$, overweight: $25-29.9 \mathrm{~kg} / \mathrm{m}^{2}$, obese: $\geq 30 \mathrm{~kg} / \mathrm{m}^{2}$ ) indices without the age difference and in relation to the number of monitored groups: I. - BMI within the standard and WHR above average; II. - BMI overweight and WHR above average; III. - BMI obese and WHR above average; IV. - BMI overweight and WHR within the standard; V. - BMI obese and WHR within the standard. Using the variance analysis for the repeated measurements we observed whether the person with "better" WHR and BMI parameters achieved higher PA values. As a post hoc test of the variance analysis to monitor differences in the pairs we chose the Scheffe test. The statistical significance was set at the $p<.05$ level.

\section{Results}

The influence of courses in weight reduction to the selected somatic characteristics

The monitored group was divided into two groups, namely women with the lower $(8,000$ footsteps/day) and increased (12,000 footsteps/day) PA in accordance with the achieved PA during the course of the weight loss program (Table 1). Table 2 presents the descriptive characteristics of the somatic parameters for each sub-group differentiated by age and the level of PA.
The TBW does not exceed the 50\% threshold in all subgroups. Younger and older women who carried out the higher level of PA achieved lower average in the Cf, BMI, WHR, BFM and VFA parameters than women with lower level of PA, the differences were not statistically significant. The highest average values of somatic parameters were observed in older women with lower PA. In all sub-groups the BC health indicators showed significant risk values. Following the therapy, the FFM in all sub-groups remained the same or a showed slight decrease. The average value of FFMI and BCMI decreased very slightly, by a maximum of 0.2 units. After the course we observed significant reduction in the waist and gluteal Cf. Reduction in all measured BC parameters associated with risk aspects of obesity occurred, although the differences were not statistically significant. Statistically significant difference $(p<.001)$ after the course was found only between the age sub-groups in the amount of VFA.

Nearly homogeneous values in the relative BFP were found in younger women engaged in lower PA (BFP: $40.6 \%$ ) and older women with the higher physical activity (BFP: 40.9\%) (Table 2).

Relative health risk as measured by the somatic indexes (BMI, WHR, BFMI, FFMI, VFA and OI) is high. Based on the Obesity Index sub-groups are classified as severely obese (OI > 120\%). The BMI average values before therapy were in the obesity category (BMI: $\geq 30$ ). Following the therapy, the sub-groups of younger and older women with increased PA, moved to the overweight category (BMI: $25-29.9 \mathrm{~kg} / \mathrm{m}^{2}$ ).

Table 1

Number of footsteps per day within each week in relation to age and physical activity

\begin{tabular}{|c|c|c|c|c|c|c|c|c|}
\hline \multirow{3}{*}{$\begin{array}{r}\text { Age group } \\
\text { Level of PA }\end{array}$} & \multicolumn{4}{|c|}{$<40$ years } & \multicolumn{4}{|c|}{$\geq 40$ years } \\
\hline & \multicolumn{2}{|c|}{ Lower } & \multicolumn{2}{|c|}{ Higher } & \multicolumn{2}{|c|}{ Lower } & \multicolumn{2}{|c|}{ Higher } \\
\hline & $M$ & $S D$ & $M$ & $S D$ & $M$ & $S D$ & $M$ & $S D$ \\
\hline Week 1 & 8,107 & 1,897 & 11,567 & 2,176 & 7,431 & 2,383 & 10,813 & 2,617 \\
\hline Week 2 & 8,950 & 1,796 & 11,828 & 2,537 & 8,158 & 2,860 & 12,658 & 2,356 \\
\hline Week 3 & 9,187 & 2,031 & 14,000 & 2,981 & 7,965 & 2,467 & 13,053 & 3,756 \\
\hline Week 4 & 8,246 & 1,679 & 12,693 & 2,656 & 7,594 & 2,385 & 13,066 & 1,999 \\
\hline Week 5 & 8,419 & 1,976 & 12,546 & 3,015 & 7,504 & 2,377 & 12,638 & 2,312 \\
\hline Week 6 & 9,063 & 1,844 & 12,421 & 2,448 & 7,953 & 2,125 & 11,918 & 2,227 \\
\hline Week 7 & 8,057 & 1,633 & 12,206 & 1,661 & 7,651 & 2,273 & 13,025 & 2,411 \\
\hline Week 8 & 8,627 & 1,454 & 12,613 & 1,914 & 7,634 & 2,262 & 12,804 & 2,177 \\
\hline Week 9 & 8,073 & 1,730 & 11,593 & 2,200 & 7,994 & 2,108 & 12,337 & 2,651 \\
\hline Week 10 & 8,124 & 1,404 & 12,790 & 1,685 & 7,450 & 2,098 & 12,680 & 2,500 \\
\hline Week 11 & 8,289 & 2,180 & 12,337 & 2,319 & 8,096 & 1,983 & 12,937 & 2,344 \\
\hline Mean Week & 8,467 & 1,784 & 12,418 & 2,327 & 7,766 & 2,302 & 12,539 & 2,486 \\
\hline
\end{tabular}

Note. $\quad \mathrm{PA}=$ physical activity. 


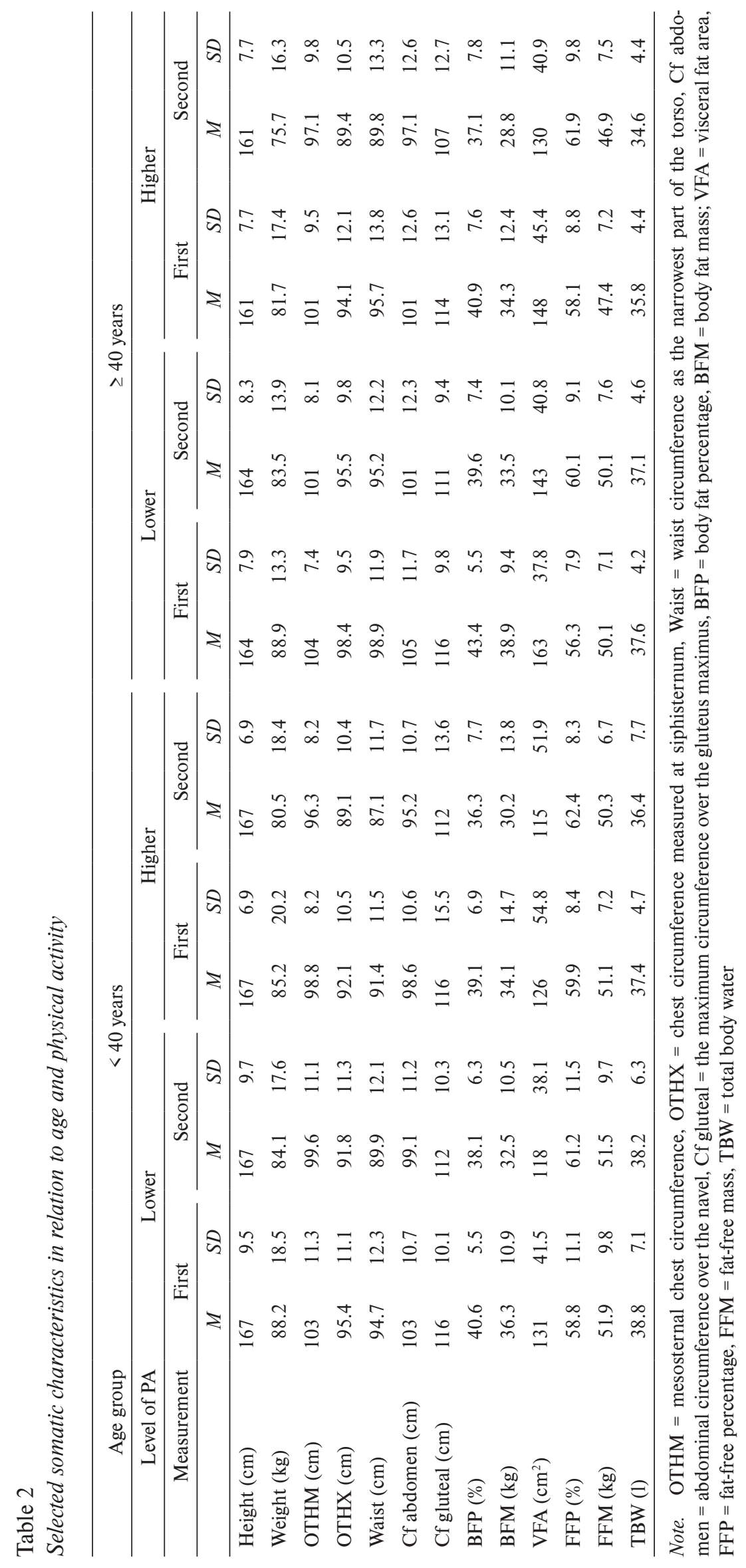




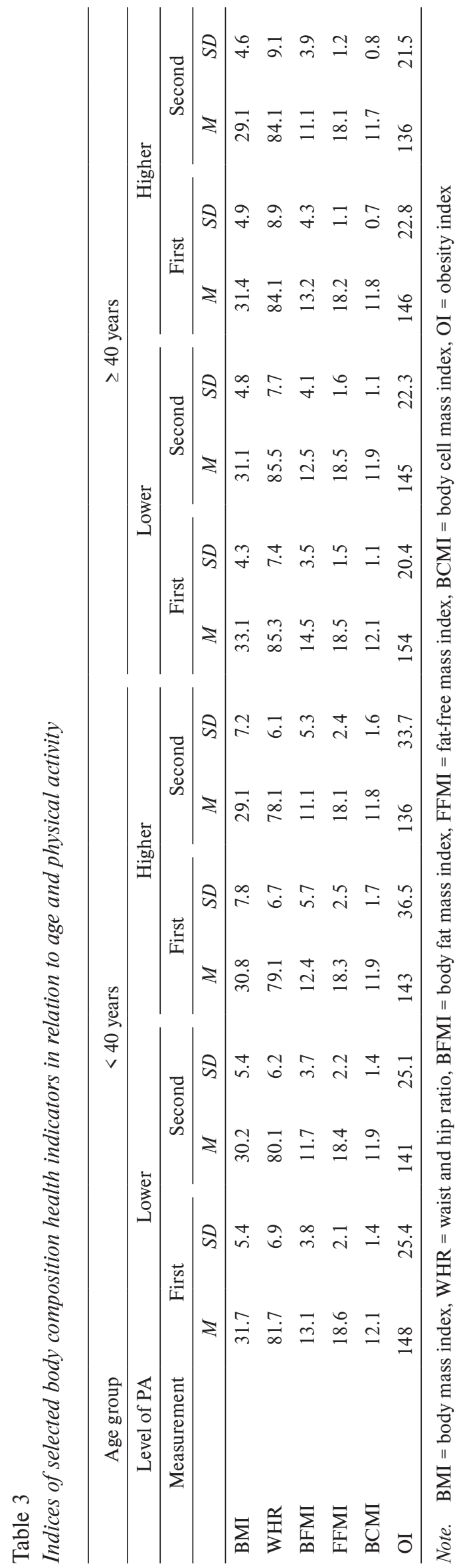

The BFMI $\left(\geq 11.8 \mathrm{~kg} / \mathrm{m}^{2}\right)$ indicated high health risk for all sub-groups, even after the course. The average values of the FFMI and BCMI for all sub-groups corresponded to the recommended values for women. In younger women with lower PA (BMI: $31.7 \pm 5.4 \mathrm{~kg}$ / $\mathrm{m}^{2}$; BFMI: $\left.3.1 \pm 3.8\right)$ and among older women with higher PA (BMI: $31.4 \pm 4.9 \mathrm{~kg} / \mathrm{m}^{2}$; BFMI: $13.2 \pm 4.3$ ) we recorded almost identical BMI and BFMI values (Table 3).

\section{Connection between PA and BMI \& WHR classification}

During the result evaluation we also took into account the degree and type of obesity using a combination of WHR and BMI indices without taking into the account difference in age, however in relation to the number of respondents. Based on this classification we observed a positive change in 22 women (Table 4 ), which occurred in the WHR index reduction, namely from category 2 to category 4 and from category 3 to category 5. Positive adjustment also occurred in the BMI index from category 3 to 2 and from category 5 to 4 . In women affected by these changes and who clearly changed their body shape proportions we noted, from the course's half way stage, increased average daily activity (Figure 1).

Table 4

Numerical representation number of women in each subgroup according to the BMI \& WHR classification

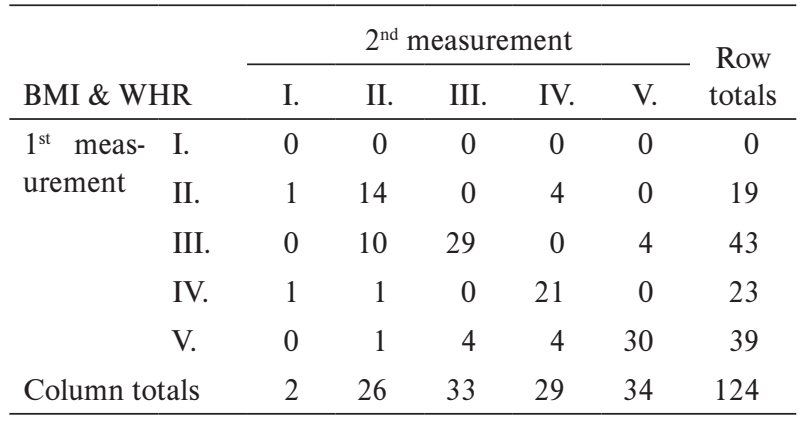

Note. $\mathrm{I}$. = BMI within the standard and WHR above average, II. = BMI overweight and WHR above average, III. = BMI obese and WHR above average, IV. = BMI overweight and WHR within the standard, V. = BMI obese and WHR within the standard

\section{Discussion}

Attending the weight reduction course is fitting for the onset of lifestyle change and to achieve weight loss. STOB courses are in essence based on the cognitive behavioural therapy, encouragement of adherence to the weight loss program and promotion of intrinsic motivation. Inclusion among obese women helps to overcome the feeling of hunger and muscle fatigue in the new PA lifestyle. 


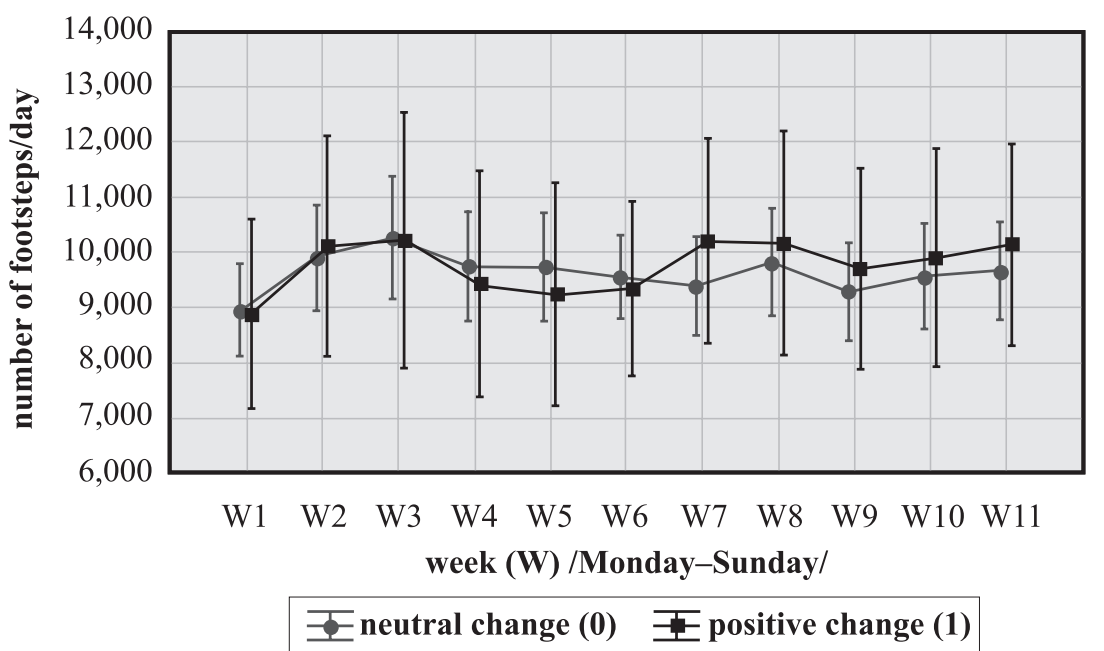

Figure 1. Average physical activity (number of footsteps/week) according to women's categories in relation to the positive or without change

The most variable component of body weight is fat, which is a major factor in the $\mathrm{BC}$ variability and is easily tractable by developmental aspects and PA (Riegerová, Přidalová, \& Ulbrichová, 2006). Based on the average BFP according Heyward and Wagner (2004) both age groups of women were classified as obese (> 35\%). The increase in the fat component in relation to aging confirmed, for example, studies by Kyle, Genton, Slosman, and Pichard (2001). Guo, Zeller, Chumlea, and Siervogel (1999) state that in adulthood the total amount of BFM increases by about $0.37 \mathrm{~kg}$ per year in men and $0.41 \mathrm{~kg}$ in women.

Body fat reduction is a difficult process, which should be carried out under supervision. In principle, it can be divided into two separate stages - in the first stage the excess body fat is reduced; in the second stage, there should be changes in the patient's lifestyle, aimed at maintaining the reached weight. Using complex intervention, including guided PA, diet, and cognitive behavioural therapy, it proved desirable changes in the anthropometric indicators measured via multi-frequency bio-impedance analysis measurement (Poděbradská, Stejskal, Schwarz, \& Poděbradský, 2011).

Therapy contributed to the fat content percentage reduction from $2.4 \%$ to $3.8 \%$. The highest fat loss was found in older women (3.8\%). Reciprocal relationship exists between TBW and BFP.

Obese people have low TBW, only $45 \%$ of the body weight. Rokyta (2000) refers to TBW only $10 \%$ in adipose tissue. Schoeller (1989), Bedogni et al. (2002), Ling et al. (2011) point to the decrease in TBW in relation to aging. Přidalová et al. (2008) and Přidalová and Sofková (2011) also proved that the Czech women decrease the TBW with age, increase the BMI and BFM.

Before the course commencement the fat-free percentage (FFP) was in the range of $56.3 \%$ to $59.9 \%$. The highest percentage was found in younger women with higher PA (59.9\%) after the course their FFP increased by $2.5 \%$. After the course completion the FFMI remained almost constant and this may be positively assessed. This finding is consistent with other authors' results (Donnelly et al., 2003; Garrow, \& Summerbell, 1995); weight reduction is due not only to a change of dietary habits, but also to the effect of physical activity.

Gába and Přidalová (2013) emphasized that when FFM decreased slightly with age, the body weight increased due to the increase in the BFM.

VFA within all sub-groups showed substantial health risk and at baseline ranged from $125.8 \mathrm{~cm}^{2}$ to $165.1 \mathrm{~cm}^{2}$. After the therapy there was a reduction in VFA values from 11.2 to $20.0 \mathrm{~cm}^{2}$. The largest reduction was observed in older women with lower levels of PA $\left(20 \mathrm{~cm}^{2}\right)$. The smallest reduction was observed in younger women with higher level of PA $\left(11.2 \mathrm{~cm}^{2}\right)$.

Distribution of body fat is genetically governed and is in part hormonally regulated thus we were able to observe the fat redistribution from the body periphery to abdomen in postmenopausal women (Toth, Tchernof, Sites, \& Poehlman, 2000). Higher levels of visceral fat determine abdominal obesity, which is one of the main assessment criteria of the metabolic syndrome and has, almost, the comparable predictive value for major cardiovascular events such as increased levels of LDL cholesterol (Dukát et al., 2007).

Kyle, Morabia, Schutz, and Pichard (2004) classified under the category of obesity $\left(\mathrm{BMI}>30 \mathrm{~kg} / \mathrm{m}^{2}\right.$ ) 
BFMI to be $\geq 11.8$ and FFMI to be $\geq 18.2$. We found similar results in our sub-groups.

According to Talluri et al. (2003) the index of metabolically active cells (BCMI, Body Cell Mass Index; 11.9 to 12.1 ) corresponds to the health recommendations for women. Minimum values found in our groups meet these recommendations.

For younger, less active women, the average number of footsteps was identified as 8,467 per day and in older women only 7,766 footsteps per day. These women may be, according to Tudor-Locke and Bassett (2004), classified as somewhat active individuals. Women with the higher amounts of PA can be classified as highly active. In younger women with higher PA we found 12,418 footsteps per day and in older women 12,539 footsteps per day.

Research provide preliminary support for approximately $>9,000$ steps/day associated with body composition benefits, and approximately $<5,000$ indicative of an index for sedentarism related to unhealthy body composition (Tudor-Locke et al., 2001).

Poděbradská, Stejskal, Schwarz, and Poděbradský (2011) have shown correlation between the HPA and changes in BFM and HPA and in VFA - increase in HPA leads to the increase in reduction of BFM and VFA.

PA increase showed greater decreases in BFM and maintenance of the FFP (Přidalová, Sofková, Dostálová, \& Gába, 2011). This is confirmed by Kyle et al. (2004) results, which show that PA reduces the BFM and that changes to FFM are minimal.

Ross and Janiszewski (2008) and King, Hopkins, Caudwell, Stubbs, and Blundell (2009) demonstrated that PA provides health benefits even without changes in anthropometric indicators thus reduces the risk of obesity complications, improves mental well-being and leads to better adherence to the weight loss regime. Exercise itself does not always have to lead to large loss of body mass, however it has a number of positive effects related to, among others, increased energy expenditure and improvement in long term adherence to the reduction program (Máček \& Radvanský, 2013; Racette, Deusinger, \& Deusinger, 2003).

This study was limited by the fact that it was not possible to compare the women undergoing the intervention with a control group without intervention.

\section{Conclusions}

Based on the monitoring of the PA and $\mathrm{BC}$ health risk indicators the effect of the exercise program, which included cognitive behavioural therapy, showed decline in BMI and BFP and in the decrease of VFA. The amount of FFM remained the same.

In younger women with lower PA and among older women with higher PA we find almost identical BFP and average values of the BMI and BFMI indices.

The biggest change in the sense of body firming, respectively in the increase of FFM and in the reduction of BFM, was found in older women, in both categories selected according to the level of PA.

In terms of the PA level assessment, the monitored groups were classified as somewhat physically active and highly active. It is clear that monitoring of the PA by pedometers is highly motivating for obese women.

Based on the classification according to BMI and WHR we found higher PA in women who positively changed their body shape proportions. In these women we also found that from the middle of the course they further increased the average daily PA.

Taking part in weight reduction course, positive approach to health promotion and healthy lifestyle can lead to reduced health problems associated with obesity.

\section{Acknowledgment}

The study has been supported by the research grant from the Ministry of Education, Youth and Sports of the Czech Republic (No. MSM 6198959221) "Physical Activity and Inactivity of the Inhabitants of the Czech Republic in the Context of Behavioral Changes" and IGA UP (FTK_2012_030) "The Relationship between the Health Indicators and Physical Activity in Obese and Overweight Women".

\section{References}

Albright, C., \& Thompson, D. L. (2006). The effectiveness of walking in preventing cardiovascular disease in women: A review of the current literature. Journal of Women's Health, 15, 271-280.

Andersen, R. E. (2003). Obesity. Etiology assessment treatment and prevention. Champaign, IL: Human Kinetics.

Anderson, P. M., \& Butcher, K. E. (2007). Childhood obesity: trends and potential causes. The Future of Children, 16(1), 19-45.

Anderson, G., \& Horvath, J. (2004). The growing burden of chronic disease in America. Public Health Report, 11, 263-270.

Ball, K., Crawford, D., \& Owen, N. (2000). Too fat to exercise? Obesity as a barrier to physical activity. Australian and New Zealand Journal of Public Health, 24, 331-333.

Basset, J. R., Schneider, D. R. P. L., \& Huntington, G. E. (2004). Physical activity in an old order Amish community. Medicine \& Science in Sports \& Exercise, 36(1), 79-85. 
Bedogni, G., Malavolti, M., Severi, S., Poli, M., Mussi, C., Fantuzzi, A. L., \& Battistini, N. (2002). Accuracy of an eight point tactile-electrode impedance method in the assessment of total body water. European Journal of Clinical Nutrition, 56, 1143-1148.

Biospace. InBody 720 - The precision body composition analyzer (User's manual). Retrieved from http://www.e-inbody. $\mathrm{com} / 2008$

Bravata, D. M., Smith-Spangler, C., Sundaram, V., Gienger, A. L., Lin, N., Lewis, R., ... Sirard, J. R. (2007). Using pedometers to increase physical activity and improve health. Journal of the American Medical Association, 298, 2296-2304.

Cibula, D., Henzl, M. R., \& Živný, J. (2002). Základy gynekologické endokrinologie [Fundamentals of gynaecological endocrinology]. Praha: Grada.

Czech statistical office. (2010). Statistická ročenka České republiky 2010 [Statistical yearbook of the Czech Republic 2010]. Praha: Scientia.

Donnelly, J. E., Hill, J. O., Jacobsen, D. J., Potteiger, J., Sullivan, D. K., Johnson, S. L., ... Washburn, R. A. (2003). Effects of 16 month randomized controlled exercise trial on body weight and composition in young, overweight men and women. Archives of Internal Medicine, 163, 1343-1350.

Dukát, A., Lietava, J., Krahulec, B., Čaprnda, M., Vacula, I., Sirotiaková, J., ... Minárik, P. (2007). Prevalencia abdominálnej obezity na Slovensku, študia IDEA Slovakia [The prevalence of abdominal obesity in Slovakia. The IDEA Slovakia study]. Vnitřni lékařství, 53, 326-330.

Fanta, M. (2007). Kontracepce v perimenopauze [Contraception in perimenopause]. Sanquis, 54, 18.

Gába, A., Pelclová, J., Přidalová, M., Riegerová, J., Dostálová, I., \& Engelová, L. (2009). The evaluation of body composition in relation to physical activity in 56-73 years old women: A pilot study. Acta Universitatis Palackianae Olomucensis. Gymnica, 39(3), 21-30.

Gába, A., \& Přidalová, M. (2014). Age-related changes in body composition in a sample of Czech women aged 18-89 years: A cross-sectional study. European Journal of Nutrition, 53, 167-176.

Garrow, J. S., \& Summerbell, C. D. (1995). Meta-analysis: Effect of exercise, with or without dieting, on the body composition of overweight subjects. European Journal of Clinical Nutrition, 49, 1-10.

Guo, S. S., Zeller, C. H., Chumlea, C. W., \& Siervogel, R. M. (1999). Aging, body composition, and lifestyle: The Fels Longitudinal Study. American Journal of Clinical Nutrition, 70, 405-411.

Heyward, V. D., \& Wagner, D. R. (2004). Applied body composition assessment. Champaign, IL: Human Kinetics.

Hornbuckle, L. M., Bassett, D. R., \& Thompson, D. L. (2005). Pedometer-determined walking and body composition variables in African-American women. Medicine \& Science in Sports \& Exercise, 37, 1069-1074.

Kang, M., Marshall, S. J., Barreira, T. V., \& Lee, J. (2009). Effect of pedometer-based physical activity interventions: A meta-analysis. Research Quarterly for Exercise and Sport, $80(3), 648-655$.

King, N. A., Hopkins, M., Caudwell, P., Stubbs, R. J., \& Blundell, J. E. (2009). Beneficial effects of exercise:
Shifting the focus from body weight to other markers of health. British Journal of Sports Medicine, 43, 924-927.

European Communities Commission. (2007). Bílá kniha o sportu - Strategie pro Evropu týkající se zdravotnich problémů související s výživou, nadváhou a obezitou [White paper on a strategy for Europe on nutrition, overweight and obesity related health issues]. Brussels: Author.

Kyle, U. G., Genton, L., Slosman, D. O., \& Pichard, C. (2001). Fat-free and fat mass percentiles in 5225 healthy subjects aged 15 to 98 years. Nutrition, 17, 534-541.

Kyle, U. G., Morabia, A., Schutz, Y., \& Pichard, C. (2004). Sedentarism affects body fat mass index and fat-free mass index in adults aged 18 to 98 years. Nutrition, 20, 255-260.

Láchová, J., \& Daňková, Š. (2010). Evropské výběrové šetření o zdravotním stavu v ČR - EHIS CR: Index tělesné hmotnosti, fyzická aktivita, spotřeba ovoce a zeleniny [European health interview survey in CR - EHIS CR: Body Mass Index, physical activity, consumption of fruits and vegetables]. Aktuální informace Ústavu zdravotnických informací a statistiky České republiky, 70, 1-11.

Ling, C. H. Y., De Craen, A. J. M., Slagboom, P. E., Gunn, D. A., Stokkel, M. P. M., Westendorp, R. G. J., \& Maier, A. B. (2011). Accuracy of direct segmental multi-frequency bioimpedance analysis in the assessment of total body and segmental body composition in middle-aged adult population. Clinical Nutrition, 30, 610-615.

Lubans, D. R., Morgan, P. J., \& Tudor-Locke, C. (2009). A systematic review of studies using pedometers to promote physical activity among youth. Preventive Medicine, 48, 307-315.

Máček, M., \& Radvanský, J. (2013). Fyziologie a klinické aspekty pohybové aktivity [Physiology and clinical aspects of physical activity]. Praha: Galén.

Málková, I. (2005). Hubneme s rozumem, zdravě a natrvalo [Reasonable, healthy and permanent loss of weight]. Praha: Smart Press.

Mazzeo, R. S., Cavanagh, P. R., Evans, W. J., Fiatarone, M., Hagberg, J., McAuely, E., \& Startzell, J. (1998). Exercise and physical activity for older adults. Medicine \& Science in Sports \& Exercise, 30, 992-1008.

McKinley, S. M., Brambilla, D. J., \& Posner, J. G. (1992). The normal menopause transition. Maturitas, 14, 103-115.

Miles, M. (2007). Disability and deafness in East Asia: Social and educational responses, from Antiquity to recent times. Retrieved from http://independentliving.org/docs7/ miles200708.html

Organisation for Economic Co-operation and Development (OECD). (2010). Health at a glance: Europe 2010. Paris: Author.

Payn, T., Pfeiffer, K. A., Hutto, B., Vena, J. E., Lamonte, M. J., Blair, S. N., \& Hooker, S. P. (2008). Daily steps in midlife and older adults: relationship with demographic, self-rated health, and self-reported physical activity. Research Quarterly for Exercise and Sport, 79, 128-132.

Poděbradská, R., Stejskal, P., Schwarz, D., \& Poděbradský, J. (2011). Physical activity as a part of overweight and obesity treatment. Acta Universitatis Palackianae Olomucensis. Gymnica, 41(4), 17-27.

Přidalová, M., Riegerová, J., Dostálová, I., \& Gába, A. (2008). Effects of cognitive behavioral psychotherapy 
on body composition and constitution. Acta Universitatis Palackianae Olomucensis. Gymnica, 38(2), 13-23.

Přidalová, M., Sofková, T., Dostálová, I., \& Gába, A. (2011). Vybrané zdravotní ukazatele u žen s nadváhou a obezitou ve věku 20-60 let [Selected health indicators in women with overweight nad obesity at the age of 20-60 years]. Česká antropologie, 61(1), 32-38.

Racette, S. B., Deusinger, S. S., \& Deusinger, R. H. (2003). Obesity: Overview of prevalence, etiology, and treatment. Physical Therapy, 83, 276-288.

Ready, A. E., Naimark, B., Ducas, J., Sawatzky, J. V., Boreskie, S. L., Drinkwater, D. T., \& Oosterveen, S. (1995). Walking program reduces elevated cholesterol in women post-menopause. Canadian Journal of Cardiology, 11, 905-912.

Riegerová, J., Přidalová, M., \& Ulbrichová, M. (2006). Aplikace fyzické antropologie v tělesné výchově a sportu [Application of physical anthropology in physical education and sports]. Olomouc: Hanex.

Rokyta, R. (2000). Fyziologie pro bakalárská studia v medicíně, prírodovědných a tělovýchovných oborech [Physiology: For bachelor's studies of medicine, sciences and physical education]. Praha: ISV nakladatelství.

Ross, R., \& Janiszewski, P. M. (2008). Is weight loss the optimal target for obesity - related cardiovascular disease risk reduction? Canadian Journal of Cardiology, 24, 25-31.

Roubenoff, R. (2000). Sarcopenia and its implications for the elderly. European Journal of Clinical Nutrition, 54, 40-47.

Saris, W. H. M., Blair, S. N., Van Baak, M. A., Eaton, S. B., Davies, P. S., Di Pietro, L., ... Wyatt, H. (2003). How much physical activity is enough to prevent unhealthy weight gain? Outcome of the IASO $1^{\text {st }}$ Stock Conference and consensus statement. Obesity Reviews, 4, 101-114.

Schneider, P. L., Crouter, S., \& Bassett, D. R. (2004). Pedometer measures of free-living physical activity: Comparison of 13 models. Medicine and Science in Sports and Exercise, 36, 331-335.

Schoeller, D. A. (1989). Changes in total body water with age. American Journal of Clinical Nutrition, 50, 1176-1181.

Sigmund, E., Frömel, K., \& Neuls, F. (2005). Physical activity of youth: Evaluation guidelines from the viewpoint of health support. Acta Universitatis Palackianae Olomucensis. Gymnica, 35(2), 59-68.

Sofková, T., Přidalová, M., Pelclová, J., \& Dostálová, I. (2011). Změna tukové frakce u obézních žen ve vztahu $\mathrm{k}$ doporučené pohybové aktivitě [Changes in fat fraction in obese women in relation to recommended physical activity]. Česká antropologie, 61(1), 39-44.

StatSoft, Inc. (2011). STATISTICA (data analysis software system), version 10. Tulsa, OK: Author.

Straznicky, N. E., Lambert, G. W., McGrane, M. T., Masuo, K., Dawood, T., Nestel, P. J., ... Lambert, E. A. (2009). Weight loss may reverse blunted sympathetic neural responsiveness to glucose ingestion in obese subjects with metabolic syndrome. Diabetes, 58, 1126-1132.

Swartz, A., Strath, S., Parker, S., Miller, N., \& Cieslik, L. (2007). Ambulatory activity and body mass index in white and non-white older adults. Journal of Physical Activity \& Health, 4, 294-304.

Talluri, A., Liedtke, R., Mohamed, E. I., Maiolo, C., Martinoli, R., \& Lorenzo, A. (2003). Application of body cell mass index for studying muscle mass changes in health and disease conditions. Acta Diabetologica, 40, 286-289.

Thompson, D. L., Rakow, J., \& Perdue, S. M. (2004). Relationship between accumulated walking and body composition in middle-aged women. Medicine \& Science in Sports \& Exercise, 36, 911-914.

Toth, M. J., Tchernof, A., Sites, C. K., \& Poehlman, E. T. (2000). Effect of menopausal status on body composition and abdominal fat distribution. International Journal of Obesity, 24, 226-231.

Tudor-Locke, C., \& Myers, A. M. (2001). Methodological considerations for researchers and practitioners using pedometers to measure physical (ambulatory) activity. Research Quarterly for Exercise and Sport, 72, 1-12.

Tudor-Locke, C., Ainsworth, B. E., Whitt, M. C., Thompson, R. W., Addy, C. L., \& Jones, D. A. (2001). The relationship between pedometer-determined ambulatory activity and body composition variables. International Journal of Obesity, 25, 1571-1578.

Tudor-Locke, C., \& Bassett, R. (2004). How many steps/ day are enough? Preliminary pedometer indices for public health. Sports Medicine, 34, 1-8.

U. S. Department of Health and Human Services. (2008). Physical activity guidelines for Americans. Retrieved from http://www.health.gov/paguidelines/pdf/paguide.pdf

Volgyi, E., Tylavsky, F. A., Lyytikainen, A., Suominen, H., Alen, M., \& Cheng, S. (2008). Assessing body composition with DXA and bio-impedance: Effects of obesity, physical activity, and age. Obesity, 16, 700-705.

World Health Organization (WHO). (2004). Global strategy on diet, physical activity and health. Geneva: Author. 